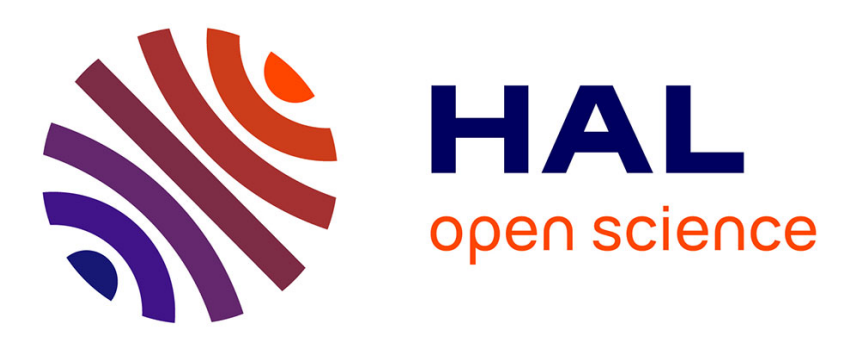

\title{
Biogeochemical responses to the removal of maricultural structures from an eutrophic lagoon (Tapong Bay) in Taiwan
}

\author{
Jia-Jang Hung, Chia-Sui Hung, Huei-Meei Su
}

\section{- To cite this version:}

Jia-Jang Hung, Chia-Sui Hung, Huei-Meei Su. Biogeochemical responses to the removal of maricultural structures from an eutrophic lagoon (Tapong Bay) in Taiwan. Marine Environmental Research, 2007, 65 (1), pp.1. 10.1016/j.marenvres.2007.07.003 . hal-00562987

\section{HAL Id: hal-00562987 \\ https://hal.science/hal-00562987}

Submitted on 4 Feb 2011

HAL is a multi-disciplinary open access archive for the deposit and dissemination of scientific research documents, whether they are published or not. The documents may come from teaching and research institutions in France or abroad, or from public or private research centers.
L'archive ouverte pluridisciplinaire HAL, est destinée au dépôt et à la diffusion de documents scientifiques de niveau recherche, publiés ou non, émanant des établissements d'enseignement et de recherche français ou étrangers, des laboratoires publics ou privés. 


\section{Accepted Manuscript}

Biogeochemical responses to the removal of maricultural structures from an eutrophic lagoon (Tapong Bay) in Taiwan

Jia-Jang Hung, Chia-Sui Hung, Huei-Meei Su

PII:

S0141-1136(07)00091-8

DOI:

10.1016/j.marenvres.2007.07.003

Reference:

MERE 3136

To appear in:

Marine Environmental Research

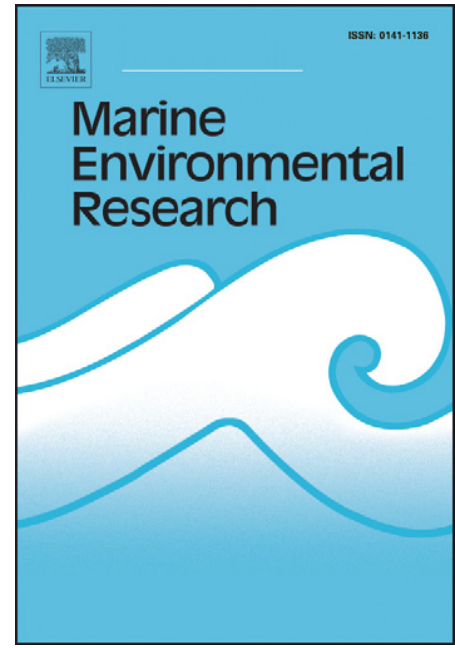

Received Date: $\quad 10$ September 2006

Revised Date: $\quad 8$ July 2007

Accepted Date: $\quad 8$ July 2007

Please cite this article as: Hung, J-J., Hung, C-S., Su, H-M., Biogeochemical responses to the removal of maricultural structures from an eutrophic lagoon (Tapong Bay) in Taiwan, Marine Environmental Research(2007), doi: 10.1016/ j.marenvres.2007.07.003

This is a PDF file of an unedited manuscript that has been accepted for publication. As a service to our customers we are providing this early version of the manuscript. The manuscript will undergo copyediting, typesetting, and review of the resulting proof before it is published in its final form. Please note that during the production process errors may be discovered which could affect the content, and all legal disclaimers that apply to the journal pertain. 


\section{Biogeochemical responses to the removal of maricultural}

\section{structures from an eutrophic lagoon (Tapong Bay) in Taiwan}

Jia-Jang Hunga*, Chia-Sui Hunga and Huei-Meei Sub

a. Institute of Marine Geology and Chemistry, National Sun Yat-Sen University, Kaohsiung, Taiwan.

Tel: 886-7-5255147, Fax: 886-7-5255130

E-mail: hungjj@mail.nsysu.edu.tw

b. Tungkang Marine Laboratory, Taiwan Fisheries Research Institute, Pingtung. Taiwan

* Corresponding author

Revised and Re-submitted to Marine Environmental Research

June 22, 2007 


\section{Abstract}

The biogeochemistry of Tapong Bay, one of the major lagoons in southern Taiwan, was studied from 1999 to 2004, encompassing a period in 2003 in which aquaculture activities were terminated and the associated structures removed.

Removal of the maricultural structures resulted in the reduction of the mean time for water exchange time in Tapong Bay from about $10 \pm 2$ days to $6 \pm 2$ days. The annual mean concentration of measured nutrients (DIN, DIP \& DSi) also decreased significantly, likely due to improved water exchange, ceased feeding and increased biological utilization. An overall high primary production was maintained and likely to be constrained by temperature, light availability and turbidity rather than by abundant nutrients throughout the study period. The change in stoichiometric ratios among inorganic and organic nutrients $(\mathrm{C} / \mathrm{N}, \mathrm{Si} / \mathrm{N}, \mathrm{N} / \mathrm{P})$ may be attributed to the shift of plankton community between the two periods. The annual mean of $\triangle \mathrm{POC} / \Delta \mathrm{PON}$ was 8.1, a little bit larger than that (7.3) before removal, also possibly resulting from the shift of planktonic community (from diatom-dominated to flagellate-dominated and increase of total phytoplankton \& zooplankton) and removal of periphyton and oysters. The Tapong Bay shows a $37 \%$ increase (from 5.6 to $7.7 \mathrm{~mol} \mathrm{C} \mathrm{m-2} \mathrm{yr-1)} \mathrm{in}$ net ecosystem production (NEP) after structure removal, although the increase was not statistically significant. The change in environmental conditions has therefore 
influenced profoundly the carbon and nutrient biogeochemical processes and budgets

in the semi-enclosed ecosystem.

Keywords: Carbon; Nutrient; Biogeochemical processes; Budgets; Environmental change; Tapong Bay

\section{Introduction}

Tapong Bay is a tropical lagoon located on the southwestern coast of Taiwan.

The lagoon is relatively shallow and has been extensively exploited as maricultural farms for decades, during which the lagoon was occupied largely by oyster culture racks and caged fishery structures. The cultured oysters and fishes tend to release nutrients into the lagoon via recycling from excretion (Souchu et al., 2001) and remineralization of feces and pseudofeces (Reusch \& Williams, 1998). The lagoon ecosystem has undergone eutrophication due to poor circulation and continuous inputs of nutrients and organic matter from internal and external sources, as the lagoon was also surrounded by watersheds extensively used for urban and aquacultural purposes (Hung \& Hung 2003; Hung et al., 2003). In recent years, the government has initiated a grand plan to develop Tapong Bay as a central part of the National Scenic and Recreational Park. The lagoon-associated environments were cleaned up with the complete removal of the maricultural structures from the lagoon around January 2003.

Tapong Bay was previously reported to be an autotrophic ecosystem with a sink for carbon dioxide (Hung \& Hung, 2003). A net nitrogen fixation was also found before the removal of maricultural structures (Hung \& Hung, 2003). There 
was no evidence of any change in biogeochemical processes and ecosystem functioning after the removal of surface structures. Although the water quality of the lagoon was expected to improve, primary production could change significantly and shift the trophic states, as oysters were totally removed and rack-associated periphytons would largely vanish after the removal of surface structures. Accordingly, Tapong Bay was a near ideal site for documenting the biogeochemical responses to controlled ecosystem changes. Thus, this study aims to illustrate and compare the biogeochemical dynamics and budgets of carbon and nutrients before and after the removal of maricultural structures from the lagoon.

\section{Materials and methods}

\subsection{Study site}

Tapong Bay is a small and semi-enclosed coastal lagoon in southwestern Taiwan $\left(22^{\circ} 27^{\prime} \mathrm{N}, 120^{\circ} 26^{\prime} \mathrm{E}\right)$ (Fig. 1). The total area of the lagoon is around $5.32 \mathrm{~km}^{2}$, and it has a volume of approximately $11.6 \times 10^{6} \mathrm{~m}^{3}$. The depth ranges from $1 \mathrm{~m}$ near the tidal inlet to $6 \mathrm{~m}$ in the inner bay with a mean depth of $2.2 \mathrm{~m}$. Water exchange between Tapong Bay and Taiwan Strait is driven primarily by a semi-diurnal dominated tide, which is somewhat restricted by exchanging water through a narrow tidal inlet. In addition to direct input of precipitation, the terrestrial water input via the Lipan Dike is derived mainly from urban and aquacultural wastewater with a moderate salinity $(<20)$. The lagoon was farmed extensively with hanged oysters and caged fishes, but all maricultural structures were completely removed around January 2003.

Temperature and rainfall patterns differed between dry (October - April) and wet 
(May-September) seasons. The temperature of lagoon water, which might respond quickly to the change of air temperature, and ranged from about $22{ }^{\circ} \mathrm{C}$ in winter (dry season) to $32^{\circ} \mathrm{C}$ in summer (wet season) (Hung \& Hung, 2003). Spring and fall seasons are transition periods and last only 1-2 months each. Northeastern and southwestern monsoons prevail respectively during the dry and wet seasons, which also affect the mixing of lagoon water. Table 1 shows that total inputs of precipitation and wastewater are much greater in the wet season than in the dry season. Because of small lagoon volume, lagoon salinity was subject to seasonal variability, ranging from 25.4 in August 2000 to 35.1 in May 2003, regardless of removal of the structures during the study period.

\subsection{Sampling and analytical methods}

Water samples were collected from Tapong Bay (Sta. $1 \sim$ Sta. 10, Fig. 1), Lipan

Dike, and the adjacent coastal sea, before (from August 1999 to July 2002) and after (from February 2003 to September 2004) removal of the maricultural structures.

Samples were taken bi-monthly before structure removal but were taken either bi-monthly or quarterly after structure removal because of restricted access. Water samples were collected from upper, middle and bottom layers using a peristaltic pump and a pre-cleaned silicone tube. Dissolved oxygen (DO) was measured in situ with a portable DO meter (YSI 52) calibrated by the method of direct spectrophotometry of total iodine (Pai et al., 1993). The reproducibility was better than 3\%. Water column $\mathrm{pH}$ was measured in situ with a portable $\mathrm{pH}$ meter (Mettler MP-120) with reproducibility better than \pm 0.02 . Salinity was determined with an Autosal salinometer (Guildine $8400 \mathrm{~B})$ in the laboratory to gain precise salinity values $( \pm 0.002)$ 


\section{ACCEPTED MANUSCRIPT}

for deriving salt and water budgets. Chlorophyll $a$ samples were collected in situ by filtering $100 \mathrm{ml}$ water through $\mathrm{GF} / \mathrm{F}$ filters that were frozen in the dark until analyses in the laboratory. Another four liters of each sample were stored in a polyethylene bottle and brought back to the laboratory immediately for further quantitative filtration and analyses.

A part of each water sample was filtered through pre-combusted $\mathrm{GF} / \mathrm{F}$ filters (at $450{ }^{\circ} \mathrm{C}, 4 \mathrm{hr}$ ). The filtered water was used to measure dissolved nutrients, dissolved organic carbon (DOC), nitrogen (DON) and phosphorus (DOP). Three replicate measurements were made for each chemical analysis. Dissolved inorganic nitrogen $\left(\mathrm{NO}_{3}+\mathrm{NO}_{2}+\mathrm{NH}_{4}\right.$, hereafter DIN), phosphate $\left(\mathrm{PO}_{4}{ }^{3-}\right.$, hereafter DIP) and silicate $\left(\mathrm{H}_{4} \mathrm{SiO}_{4}\right.$, hereafter Dsi) were determined colorimetrically (Grasshoff et al., 1983) with an UV-VIS spectrophotometer equipped with a flow injection analysis. Precision was better than 5\%. DOC was measured by the high temperature catalytic oxidation method (Shimadzu TOC 5000) (Hung et al., 2000) with precision better than $4 \%$. DON was determined from the difference between total dissolved nitrogen (TDN) and dissolved inorganic nitrogen. TDN was measured with the high temperature oxidation and chemiluminescent detection (Antek N/S analyzer) with reproducibility within $\pm 8 \%$ for seawater $(n=8)$. DOP was determined from the difference between dissolved inorganic phosphate and total dissolved phosphorus (TDP) that was measured by the UV-persulfate oxidation and colorimetric method (Ridal \& Moore, 1990). Reproducibility of TDP measurement in seawater $(\mathrm{n}=8)$ was $\pm 7 \%$. 
Chlorophyll $a$ was extracted with $90 \%$ acetone and determined with a Turner Design 10-AU fluorometer (Welschmeyer, 1994). Phytoplankton production and dark community respiration were determined with oxygen evolution and consumption, respectively, by conducting incubation experiments conducted outdoors near the Tapong Bay. Seawater samples were generally collected at low tide in the early morning, separated into 300-ml BOD bottles, and incubated under light and dark conditions by running surface seawater to maintain temperature at ambient levels. The light bottles were incubated at $100 \%, 50 \%$ and $20 \%$ of the surface irradiance by shading with different black screens. Both light and dark incubations were run for at least 6 hrs. Net production (NP) and respiration rates $\left(\mathrm{mmol} \mathrm{O}_{2} \mathrm{~m}^{-2} \mathrm{~h}^{-1}\right)$ were derived from changes in DO concentrations monitored at initial and final incubations. Concentrations of DO were measured by a spectrophotometric method adapted from the Winkler titration (Pai et al., 1993). Net production and respiration rates were expressed as carbon equivalent rates by using 1.2 as photosynthetic and respiration quotients. Gross production (GP) was estimated as the sum of NP and respiration rate.

Particulate matter samples collected on GF/F filters were used for analyses of particulate organic carbon (POC) and nitrogen (PON). The filtered samples were placed in silver boats and then determined for POC and PON with a C/N/S analyzer (Fisons NCS 1500) after removing the inorganic carbon with 2 M hydrochloric acid (Hung et al. 1999). The blank value attributed to pre-combusted GF/F filter and silver boat were deduced from the raw value of a sample concentration; the precision was $\pm 0.3 \mu \mathrm{M} \mathrm{C}$ and $\pm 0.2 \mu \mathrm{M} \mathrm{N}$. 


\subsection{Biogeochemical modeling approach}

The biogeochemical fluxes and metabolism of nutrients and carbon in the lagoon were evaluated by using the LOICZ biogeochemical budget model (Smith et al. 1991; Gordon et al. 1996; Smith \& Hallibaugh, 1997). The fundamental principles of modeling are that non-conservative nutrient and carbon budgets can be constructed from non-conservative distributions of nutrients and water budgets, which in turn are constrained from the salt balance. The non-conservative flux of a material is estimated from the flux deviation between inputs and outputs based on salt and water balances. The non-conservative flux of dissolved inorganic phosphorus is assumed to be an approximation of net metabolism, as phosphorus is not involved in gas-phase reactions. Nitrogen and carbon both have other major pathways, such as denitrification, nitrogen fixation, and gas exchange across the air-sea interface, and calcification. The biogeochemical pathways of carbon can be approximated from non-conservative phosphorus flux and C-P stoichiometric ratio of reactive particles in the lagoon. Details of modeling and carbon-budget derivation can be found from the LOICZ web site (http://www.loicz.org/) and Smith \& Hallibaugh (1997) or from Hung \& Hung (2003) for those budgets in the before removal period. Because the distinct variability in wastewater and material inputs with time, the non-steady state method (Smith \& Hallibaugh ,1997) was applied to derive water, nutrient and carbon budgets for each sampling period. Those two-month and/or quarter block-averaged budgets were integrated to give an annual budget for both before and after structure removal..

\section{Results and discussion}




\section{ACCEPTED MANUSCRIPT}

\subsection{Hydrological variability throughout the study period}

As Tapong Bay is a small and choked lagoon with only one tidal inlet for water exchange and a dike (Lipan) allowing brackish water to flow in, the spatial and temporal variability of hydrological conditions were likely to be determined by the seasonal rainfall pattern and tidal dynamics. The study area encompasses a wet season with southwest monsoon prevailing from May to September, and a dry season with northeast monsoon prevailing from October to April (Water Resources Planning Commission, 1997). Thus, temporal variability of lagoon-averaged temperature was parallel to the seasonal change in air temperature through the whole study period

(Table 1). Although the structure removal may increase surface temperature by removing the shedding effect, it may also pose a cooling effect by improving flushing. Consequently, the temperature difference between before and after periods was not statistically significant (Table 4). Salinity distributions were closely related to precipitation and seawater exchange. Dominant semi-diurnal and diurnal tides controlled primary water exchange and subsequently drove the lagoon circulation. Two sub-anti-clockwise circulation patterns were separated generally by the middle area of lagoon in a northeast-southwest direction (Yu, 2001). This circulation pattern showed no significant difference between before and after removal of the maricultural structures (Yu, C.-S., personal communication). Therefore, the spatial pattern of salinity was similar, with higher salinity near the tidal inlet and lower salinity near the Lipan Dike in surface and bottom waters for both periods. However, the spatial gradient appears to be more pronounced in surface water than in bottom water. The salinity in summer (August) was slightly lower in 2003 (after removal) than in 1999 
(before removal) (Fig. 2), primarily due to the higher net precipitation in 2003. Spatial distribution of salinity in the dry season also shows a decreasing pattern from the outer to the inner lagoon (data omitted for brevity).

The hydrochemistry and water budgets of Tapong Bay before removal of the maricultural structures have been described by Hung and Hung (2003). Briefly, the water exchange time ranged from 7 days (summer) to 13 days (winter) with a mean of $10 \pm 2$ days. It was also longer in the inner lagoon (7-24 days) than in the outer lagoon (4-12 days). The water exchange and circulation were apparently restricted by the densely occupied maricultural structures. After removal of the maricultural structures, the water exchange time decreased to the range of 4-9 days with a mean of $6 \pm 2$ days. The differences were only significant at the $10 \%$ probability level (Table 4). As the major circulation pattern was quite similar to the previous condition before the structure removal, the water exchange time in the inner and outer lagoons after removal of the structures was reduced proportionately to the previous conditions to 5-13 days and 3-7 days, respectively. Apparently, the flushing efficiency of lagoon water was significantly improved after the surface structures were removed completely from the lagoon.

Distributions of lagoon-averaged $\mathrm{pH}$ and DO were always higher in surface than in bottom waters, resulting more likely from higher primary production and air exchange in surface than in bottom waters (Fig. 2). In addition, lower concentrations of $\mathrm{pH}$ and $\mathrm{DO}$ may also be caused by intensive respiration and organic matter decay occurring in bottom water and/or surface sediments, as more than $50 \%$ of lagoon surface sediments contain rather high TOC (4-9\%) contents (Hsieh, 2001). This 
inference was supported by the data showing higher $\mathrm{pH}$ and DO in surface water in summer than in winter. Summer stratification may be also responsible for lower DO concentrations in bottom water. The surface-bottom differences of DO distributions were significant at the $10 \%$ probability level for the before period and $5 \%$ probability level for the after period. However, the surface-bottom differences of $\mathrm{pH}$ were not statistically significant, likely due to small ranges of distributions. There was no particular trend throughout the time span of this study. Nevertheless, concentrations of DO showed a significant increase most likely due to a better condition of water flushing after the removal of surface structures (Table 1). The differences were significant at the 5\% probability level for both surface and bottom waters (Table 4). Taking summer as an example, spatial variations of DO display a strong gradient decreasing from the tidal inlet to the inner zone for both surface and bottom waters during the two study periods (Fig. 3). The differences between the highest (near tidal inlet) and lowest concentrations (inner lagoon) were significant $(<5 \%$ level) in both periods. The spatial variation of $\mathrm{pH}$ was less significant. In general, the $\mathrm{pH}$ value was slightly lower in the inner lagoon than in the outer lagoon, in bottom water than in surface water, and in summer than in winter (data omitted for brevity).

However, the $\mathrm{pH}$ differences between before and after periods were insignificant

(Table 4). Seasonal variations of flushing rates, water temperature, terrestrial inputs, biological production and respiration appeared to control the temporal and spatial distributions of $\mathrm{DO}$ and $\mathrm{pH}$ in the lagoon throughout the study period.

Hydrochemical changes may have subsequently influenced biogeochemical processes 
and budgets of nutrients and carbon after the surface structures were removed from the lagoon.

\subsection{Effects of structural removals on nutrient dynamics}

Spatial patterns of DIN and DIP (DIP omitted for brevity) distributions showed a similarly pronounced increase from the tidal inlet to the inner lagoon during the summer season (Fig. 4), reflecting the strong influence of external inputs from Lipan Dike and tidal flushing. The concentrations were significantly higher $(<10 \%$ probability level) in bottom water than in surface water, attributable to intensive biological uptake in surface water and remineralization in bottom water and sediments. Spatial distributions of DIN and DIP in other seasons, although not shown, exhibited

the same patterns as those in summer. After structure removal, the spatial patterns of nutrient distributions showed no obvious change in the lagoon. The differences between the highest (inner lagoon) and lowest (near tidal inlet) concentrations of nutrients were all significant at the $5 \%$ probability level (data not shown) in both before and after periods.

Concentrations of DIN and DIP decreased significantly over the entire lagoon in summer (Figs. 4) and in other seasons (Table 2) after removal of the surface structures. The differences were significant at the $1 \%$ probability level for DIP and 5\% probability level for DSi, but were at the $10 \%$ probability level for DIN. Concentrations of DIN, DIP and DSi ranged from 9.1 to $30 \mu \mathrm{M}$ (ave.16.4 $\mu \mathrm{M}$ ), from 1.6 to $7.6 \mu \mathrm{M}$ (ave. $4.0 \mu \mathrm{M}$ ) and from 11.0 to $39.6 \mu \mathrm{M}$ (ave. $20.3 \mu \mathrm{M}$ ), respectively, before removal of the surface structures. The concentrations decreased to 8.0-18.2 $\mu \mathrm{M}$ (ave. 11.4 $\mu \mathrm{M}$ ) for DIN, 0.2-3.0 $\mu \mathrm{M}$ (ave. 1.5 $\mu \mathrm{M}$ ) for DIP, and 4.2-19.7 $\mu \mathrm{M}$ (ave. 
$10.0 \mu \mathrm{M}$ ) for DSi after removal of the structures. Despite significant decreases in concentrations, the concentration levels are still higher than those reported for non-eutrophic lagoons (Smith et al., 1997; Smith \& Crossland, 1999; Dupra et al., 2000ab; McGlathery et al., 2001), and comparable to those in the state of eutrophication (Tada et al., 2001; Hung \& Kuo, 2002; Newton et al., 2003). The decrease in concentrations was attributed mainly to improved water flushing, which resulted in a period of 4 days shorter compared with the previous condition in water exchange time after removal of the surface structures. The increased NEP, which will be discussed in the final section, might also enhance biological uptake of nutrients and lead to lower nutrient concentrations after removal of the surface structures. This inference can be supported by the occurrence of a larger difference in concentrations between the two periods during summer with higher NEP, relative to the conditions of other seasons. In addition, the nutrient decrease could also be due to the termination of fish feeding after structure removal, although the area of caged fish farming was relatively small compared to that of oyster culture.

Compared with DIN and DIP distributions, DON distributions appear to be higher than those of DIN in both before and after removal periods. Such difference was commonly reported in most surface waters, as DON is generally derived from biological production (Hansell \& Carlson, 2001; Hung et al., 2003). Similar to other eutrophic systems (Tada et al., 2001; Anderson \& Taylor, 2001), the concentration of ammonium species was frequently equal to or greater than that of nitrate, while DON distributions generally dominated the total dissolved nitrogen in the lagoon throughout the study period. In the Tapong Lagoon, DON distributions were likely 
to be derived from both external sources (Lipan Dike) and in-situ production (Hung \& Hung, 2003). This was also true for DOC distributions. Consequently, the spatial distributions of DOC and DON followed closely that of DIN, with higher concentrations (5\% probability level) in the inner lagoon than in the outer lagoon. Despite a less distinct gradient, the concentration of DOP was also higher in the inner lagoon than in the outer lagoon for both periods.

The significant increase of DOC and DON concentrations after structure removal was largely attributed to the enhancement of gross production and nitrogen fixation (Table 3), as external inputs were not much difference between the two periods. Both gross production and nitrogen fixation not only fix carbon and nitrogen as the particulate organic form but also release them into water as the dissolved organic form. Such inference also supports the fact that DOP distributions, on the contrary, were lower than those of DIP, as well as lower in the after period than in the before period, as nitrogen fixation didn't involve DOP release. Thus, the decrease of DOP distribution may be largely determined by a better flushing condition (higher dilution effect). The differences between the two periods were only significant at the $10 \%$ probability level for DOC, DON and DOP.

\subsection{Variability in elemental ratios of nutrients}

Elemental ratios of DIN, DIP and Si are displayed in Fig. 5. The DIN/DIP ratio ranges from 1.5 to 9.2 throughout the study period, which is much lower than the Redfield ratio (16) (Redfield et al., 1963) (Fig. 5c). The low DIN/DIP ratios were likely to have been influenced by inputs of P-contaminated wastewater through the Lipan Dike with very low DIN/DIP ratios $(<2.5)$. Such ratios imply that the system 
was either biologically limited by DIN or under the condition of DIP excess. As both DIN and DIP concentrations were much higher than the critical levels (DIN $<1$ $\mu \mathrm{M}$; DIP $<0.1 \mu \mathrm{M} ; \mathrm{DSi}<2 \mu \mathrm{M}$ ) of nutrient limitation (Harrison et al., 1977; Perry \& Eppley, 1981; Nelson \& Brzezinski, 1990; Justic et al., 1995) regardless whether the structures were removed or not, the lagoon appears to be under the condition of DIP excess. Low DIN/DIP ratio is one of necessary conditions for nitrogen fixation, and this could lead to net nitrogen fixation throughout the study period. There was no particular trend in temporal variability even after the structure removal, although the DIN/DIP ratio was slightly higher in summer than in other seasons possibly due to intensive uptake of nutrients in summer.

It was much clearer that the $\mathrm{Si} / \mathrm{DIN}$ ratio was generally higher in summer (1.6-2.5) than in other seasons (0.6-1.5), except for the period of July 2002 when a lower precipitation rate perhaps induced a lower silicon input. Higher Si input and intensive DIN uptake during most summer seasons could result in Si/DIN greater than 1.0, corresponding to the ratio of diatoms (Brzezinski, 1985). The shift of plankton community structures may determine the seasonal variations of $\mathrm{Si} / \mathrm{DIN}$ ratios, as $\mathrm{Su}$ et al. (2004) reported a significant difference in plankton community between summer and winter $(p=0.05)$. In summer, the uptake of Si may decrease as the occurrence frequency of diatoms (Skeletonema costatum) decreases, and cyanobacterium Oscillatoria sp. and Chaetoceros sp. become the most common species ( $\mathrm{Su}$ et al., 2004).

Distributions of Si/DIP ratios (1.2-18.5) follow closely the seasonal patterns of Si/DIN. The consistently higher ratios in summer may also be due to higher input of 
Si and intensively biological DIP uptake in the same season. With the exception of first sampling, the ratios are lower than the typical ratio (16) in diatoms (Brzezeniski, 1985) throughout the study period, which is consistent with the above-mentioned DIP excess in the lagoon. No significant difference was found before and after removal of the surface structures.

Although we did not make systematic measurements of particulate organic phosphorus, the lagoon-averaged particulate organic $\mathrm{C} / \mathrm{N}$ ratio was slightly lower in the period before $(\mathrm{C} / \mathrm{N}=7.3)$ than after $(\mathrm{C} / \mathrm{N}=8.1)$ removal of the structures, although the differences were not statistically significant. Such ratios imply that particulate organic matter in the lagoon may be mainly of biological origin, as the $\mathrm{C} / \mathrm{N}$ ratios of external detritus were much greater (>9.2) than the Redfield ratio. Hsieh (2001) reported the values of ${ }^{13} \mathrm{C}$ in suspended POC ranging from -19.5 to $-20.7 \%$ in both periods, supporting strongly the biological origins of POC. Both $\mathrm{C}$ and $\mathrm{N}$ may not be highly enriched through biological utilization. The change in grazing impacts of zooplanktons (Lo, 2004) and periphyton distribution (Lin et al., 2005) may determine the slight change of particulate $\mathrm{C} / \mathrm{N}$ ratio after the removal of the structures.

\subsection{Comparison of gross production and biomass between the two periods}

Spatial distributions of total planktonic cell number, biomass (Chl-a) and integrated gross production (IGP) before and after removal of the structures were compared (Fig. 6). Significant correlations were found between these three parameters $(p<0.05)$. The number of cell, Chl-a and IGP increased consistently from the tidal inlet zone to the inner lagoon, and the increase was more pronounced after than before the period of structure removal. Thus, distributions of gross 
production, number of cell and Chl-a for individual samples (volumetric rates) generally correlate inversely with salinity $(p<0.01)$ but not significantly with nutrients $(p>0.05)$. The spatial distribution patterns for these three parameters are likely to be from the result of spatial gradients of salinity, water depth, water stability and/or nutrients.

All three parameters are elevated after structure removal, attributed largely to improved water quality. The increase in gross production may be mainly due to increases in DO concentrations and solar radiation availability by improving flushing efficiency and removing shading effect from the surface. Although temporal distributions of lagoon-wide integrated Chl-a do not co-vary with integrated DIN and DIP, the integrated Chl-a correlates very well with temperature, solar radiation and DO before structure removal (Fig. 7). Such relationships are largely maintained after the structure removal (data omitted for brevity). Although many experiments conducted in mesocosms and coastal systems have established the positive relationship between nutrient inputs and phytoplankton biomass or production (Twilley et al., 1985; Monbet, 1992), these systems do not generally suffer from over enrichment of nutrients. Because of high abundance of nutrients and contrasting distributions between IGP (or Chl-a) and nutrients in bottom waters of most regions of Tapong Lagoon, the lagoon-wide integrated DIN and DIP become non-critical in determining gross production. Distributions of Chl-a significantly correlate inversely with total suspended matter $(\mathrm{r}<-0.56, \mathrm{p}<0.0001)$, but correlate poorly with nutrients. Thus, gross production and biomass (Chl-a) may be primarily controlled by light availability and temperature in this lagoon with high turbidity and 
abundant nutrients. Therefore, summer distributions of cell number, Chl-a and IGP are higher than those in other seasons, and the structure removal enhances gross production and abundance of phytoplankton biomass.

It is worth noting, however, that the periphyton production attributable up to $6 \%$ of gross production before the structure removal (Lin et al., 2005) may eventually vanish after removal of the structures. The removal of major suspension feeder (oysters) and change of habitat environments may subsequently alter the food web structure and lagoon carbon budgets as well.

\subsection{Effects of structure removals on nutrient and carbon budgets}

Nutrient and carbon budgets were determined principally by water budget, nutrient and carbon distributions and internal biogeochemical processes. For a nutrient budget, the difference between total inputs and total outputs is an indication of source (inputs < outputs; positive $\Delta \mathrm{Y}$ ) or sink (inputs > outputs; negative $\Delta \mathrm{Y}$ ) in the ecosystem. Individual budget of each component for a sampling time was estimated by using the non-steady state method (Smith \& Hallibaugh, 1997) and the time interval-averaged budgets were listed in Table 3. Data show that the lagoon was a sink for DIP $(\Delta \mathrm{DIP}<0)$ for most sampling periods, and consequently a sink for an annual basis in the period before and after structure removal. There was no particular trend in seasonal patterns as $\Delta \mathrm{DIP}$ was determined by many physical (tidal fluctuation, external inputs of water and nutrients) and biogeochemical factors (internal sources, production/respiration, biological community structures). The magnitude of DIP sink is larger in the period after than before removal of the 
structures (Table 3). This is particularly interesting because the $\Delta$ DIP can be scaled up to the carbon budget according to LOICZ modeling.

Distributions of $\triangle \mathrm{DOP}$ are variable for different sampling events and exhibit a positive value $\left(0.01 \mathrm{~mol} \mathrm{~m}^{-2} \mathrm{yr}^{-1}\right)$ and a negative value $\left(-0.07 \mathrm{~mol} \mathrm{~m}^{-2} \mathrm{yr}^{-1}\right)$ before and after the structure removal, respectively. With $\Delta \mathrm{DIP}$ and $\Delta \mathrm{DOP}$, the lagoon system provides a sink for total phosphorus $(\Delta \mathrm{P}<0)$ for both periods. However, the lagoon system appears to be a source for total dissolved nitrogen $(\Delta \mathrm{N}>0)$ in both periods before and after the structure removal, and the magnitude is greater for the latter period than for the former period. This is largely due to significant sources of DON but contrasting conditions for DIN in both separated periods. This may imply that various denitrification may occur in the lagoon throughout the year, but nitrogen fixation contributes to DON pool.

The net ecosystem metabolism (NEP) derived from $\Delta \mathrm{DIP}(p-r=-106 \Delta \mathrm{DIP})$ may provide a short cut to understanding carbon budgets through nutrient budgets, as direct observations of NEP involve complicated experiments. The basic assumption is that the internal reaction flux of DIP should be proportional to production and consumption of particulate organic matter (POM) (Gordon et al., 1996), although the adsorption/desorption of DIP onto/from particulates is possible under certain environmental conditions. Assuming that DIP adsorption was almost balanced by DIP desorption during any two sampling events, the system $\Delta \mathrm{DIP}$ may then approximate the NEP of the lagoon. The system with a negative $\triangle \mathrm{DIP}$ is generally regarded as an autotrophic and net $\mathrm{CO}_{2}$ consuming system via a net production of organic matter (production $>$ respiration). In contrast, the system is heterotrophic 


\section{ACCEPTED MANUSCRIPT}

showing a net $\mathrm{CO}_{2}$ production if $\Delta \mathrm{DIP}$ is positive. The temporal variation of lagoon NEP is rather pronounced throughout the experiment (Fig. 8). The NEP is all positive except for one being negative and two approaching the balance. Thus, Tapong Lagoon exhibits clearly an autotrophic system while individual NEP(s) are averaged from two separated periods (Table 3). Before structure removals, the overall NEP $\left(5.6 \pm 6.1 \mathrm{~mol} \mathrm{C} \mathrm{m}^{-2} \mathrm{yr}^{-1}\right)$ is equivalent to $6.0 \pm 6.5 \%$ of the annual gross production (mol C m $\left.\mathrm{mr}^{-2}\right)$. After removal of the surface structures, the overall NEP $(7.7 \pm 20.4$ mol $\mathrm{C} \mathrm{m}^{-2} \mathrm{yr}^{-1}$ ) is about $5.8 \pm 15 \%$ of annual gross production

Although the mean value of NEP increased obviously (37\%) after removal of the maricultural structures, the increase (difference) was not statistically significant, primarily due to large temporal variations (standard deviations) in both before and after removal periods. It may be conservatively said that the small increase of NEP was likely due to alteration in biological community structures, leading to just a slight excess for gross production over community respiration. As producer (periphytons) and important phytoplankton consumer (oysters) were completely removed from the lagoon, the food web of lagoon should change significantly. Actually, the jellyfish, which was an important feeder of zooplanktons, almost disappeared after oyster racks were removed from the lagoon (Lo, 2004). Consequently, distributions of phytoplankton biomass and zooplankton population increased significantly after maricultural structures were removed from the lagoon. The lagoon ecosystem tends to be unstable once the structures were removed; thus, a longer period of experiment may be necessary to clarify the change of carbon budget. At current situation, the 
lagoon appears to be a carbon sink with a small increased value compared with its previous condition.

\section{Conclusion}

Tapong Bay is a semi-enclosed lagoon and an ideal site for studying the effects of environmental changes on ecosystem carbon and nutrient biogeochemical processes and budgets, as a critical land-use change occurred during the time course of this study. Before the structure removal, the lagoon was autotrophic with a net organic carbon production $\left(5.6 \pm 6.1 \mathrm{~mol} \mathrm{C} \mathrm{m}^{-2} \mathrm{yr}^{-1}\right)$. However, the lagoon system was a source of total dissolved nitrogen. After the structure removal, the lagoon remained autotrophic and the net organic carbon production increased up to $7.7 \pm 20.4 \mathrm{~mol} \mathrm{C} \mathrm{m}^{-2}$ $\mathrm{yr}^{-1}$, despite a slight increase in the state of nitrogen source. Significant changes in tidal flushing, light availability and water quality following the structure removal

were likely responsible for the enhancement of gross production. The shift of biological community structures due to alteration of habitat environments may eventually change the regimes of dark community respiration. The improvement of water quality and natural ecosystem production may provide sustainable values to compensate the economic loss caused by the exclusion of oyster and caged fishery farming previously practiced in the lagoon.

\section{Acknowledgements}

The authors greatly appreciate Drs. R. Spies (editor) and S. V. Smith (reviewer) for constructive comments in manuscript revision and Dr. J. Purcell for data analysis and discussion. We also thank Mr. S.-M. Wang, C.-M. Ho and Y.-C. Wang for their assistance in sampling and the analyses. This study was supported by the National Science Council, Taiwan, through Contracts: NSC 92-2621-Z110-003- and NSC 93-2621-Z110-001-. A partial support was given by the "Aim for the Top University Plan" of the National Sun Yet-sen University and Ministry of Education, Taiwan, 


\section{ACCEPTED MANUSCRIPT}

R.O.C. (C030214) during preparation of the manuscript.

\section{References}

Anderson, T. H., \& Taylor, G. T. (2001). Nutrient pulses, plankton bloom, and seasonal hypoxia in western Long Island Sound. Estuaries, 24, 228-243.

Brzezinski, M. A. (1985) The Si:C:N ratio of marine diatoms: interspecific variability and effect of some environmental variables. Journal of Phycology, 21, 347-357.

Dupra, V., Smith, S. V., Crossland, J. I. M., \& Crossland, C. J. (2000a) Estuarine systems of the South China Sea region: carbon, nitrogen and phosphorus fluxes. LOICZ Reports and Studies, 14, 156pp, LOICZ, Texel, The Netherlands.

Dupra, V., Smith, S. V., Crossland, J. I. M., \& Crossland, C. J. (2000b) Estuarine systems of the East Asia region: carbon, nitrogen and phosphorus fluxes. LOICZ Reports and Studies, 16, 127pp, LOICZ, Texel, The Netherlands.

Gordon, D. C. Jr., Boudreau, P. R., Mann, K. H., Ong, K. H., Silvert, W. L., Smith, S. V., Wattayakorn, G., Wulff, F., \& Yanagi, T. (1996) LOICZ Biogeochemical Modelling Guidelines. LOICZ Reports and Studies, 5,96pp, LOICZ, Texel, The Netherlands.

Grasshoff, K., Ehrhardt, M., \& Kremling, K. (1983) Methods of Seawater Analysis (Eds.), (pp. 143-187). Weinheim: Verlag Chimie.

Hansell, D. A., \& Carlson, C. A., 2001. Biogeochemistry of total organic carbon and 
nitrogen in the Sargasso Sea: control by convective overturn. Deep-Sea

Research II 48, 1649-1667.

Harrison, P. J., Conway, H. L., Holmes, R. W., \& Davis, C. O. (1993). Marine diatoms in chemostats under silicate or ammonium limitation. III. Cellular chemical composition and morphology of three diatom. Marine Biology, 43, 19-31.

Hsieh, H.-L. 2001. The detrital food web on the Kaoping coast (II): Food web of tapong lagoon. Annual Report of the National Science Council, Taiwan (in Chinese), 16pp.

Hung, J. J., Lin, C. S., Hung, G. W., \& Chung, Y. C. (1999) Lateral transport of lithogenic particles from the continental margin of the southern East China Sea. Estuarine Coastal and Shelf Science, 49, 483-499.

Hung, J. J., Lin, P. L., \& Liu, K. K. (2000) Dissolved and particulate organic carbon in the southern East China Sea. Continental Shelf Research, 20, 545-570..

Hung, J. J., \& Kuo, F. (2002) Temporal variability of carbon and nutrient budgets from a tropical lagoon in Chiku, southwestern Taiwan. Estuarine Coastal and Shelf Science, 54, 887-900.

Hung, J. J., \& Hung, P. Y. (2003) Carbon and nutrient dynamics in a hypertrophic lagoon in southwestern Taiwan. Journal of Marine Systems, 42, 99-116.

Hung, J. J., Hung, P. Y., \& Su, H. M. (2003) Water quality variability and 
eutrophication in the Tapong Bay. Journal of Chinese Environmental Protection Society, 26(1), 1-24.

Hung, J.-J., Chen, C.-H., Gong, G.-C., Sheu, D.-D., \& Shiah, F.-K., 2003. Distributions, stoichiometric patterns and cross-shelf exports of dissolved organic matter in the East China Sea. Deep-Sea Research II 50, 1127-1145.

Justic, D., Rabalais, N. N., \& Turner, R. E. (1995) Stoichiometric nutrient balance and origin of coastal eutrophication. Marine Pollution Bulletin, 30, 41-46..

Lin, H. J., Wang, T. C., Su, H. M., \& Hung, J. J. (2005) Relative importance of phytoplankton and periphyton on oyster-culture pens in a eutrophic tropical lagoon. Aquaculture, 243, 279-290.

Lo, W. T. (2005) Community structure and distribution of copepods in Tapong Bay SW of Taiwan, comparison before and after removal of oyster-culture pens. Annual Report of National Science Council, Taiwan, 26pp (in Chineses).

McGlathery, K. J., Anderson, I. C., \& Tylor, A. C. (2001) Magnitude and variability of benthic and pelagic metabolism in a temperate coastal lagoon. Marine Ecology Progress Series, 216, 1-15.

Monbet, Y. (1992) Control of phytoplankton biomass in estuaries: A comparative analysis of microtidal and macrotidal estuaries. Estuaries, 15, 563-571.

Nelson, D. M., \& Brzezinski, M. A. (1990) Kinetics of silicic acid uptake by natural diatom assemblages in two Gulf Stream worm-core rings. Marine Ecology Progress Series , 62, 283-292. 
Newton, A., Icely, J. D., Falcao, M., Nobre, A., Nunes, J. P., Ferreira, J. G., \& Vale, C. (2003) Evaluation of eutrophication in the Rio Formosa coastal lagoon, Portugal. Continental Shelf Research, 23, 1945-1961.

Pai, S. C., Gong, G., C., \& Liu, K. K. (1993) Determination of dissolved oxygen in seawater by direct spectrophotometry of total iodine. Marine Chemistry, 41 , 343-351.

Perry, M. J., \& Eppley, K. W. (1981) Phosphate uptake by phytoplankton in the central North Pacific Ocean. Deep-Sea Research, 28, 39-49.

Redfield, A. C., Ketchum, B. H., \& Rechard, F. A. (1963) The influence of organisms on the composition of sea water. In M. H. Hill (Ed.), The Sea (pp. 26-77). New York:Interscience..

Ridal, J. J., \& Moore, R. M. (1990) A re-examination of the measurement of dissolved organic phosphorus in seawater. Marine Chemistry, 29, 19-31.

Smith, S. V, Hollibaugh, J. T, Dollar, S. J., \& Vink, S. (1991) Tomales Bay metabolism: C-N-P stoichiometry and ecosystem heterotrophy at the land-sea interface. Estuarine Coastal and Shelf Science, 33, 223-257.

Smith, S. V, \& Hollibaugh, J. T. (1997) Annual cycle and interannual variability of ecosystem metabolism in a temperate climate embayment. Ecological Monographs, 67(4), 509-533.

Smith, S. V, Ibarra-Obando, S, Boudreau, P. R., \& Camacho-Ibar, V. F. (1997) Comparison of carbon, nitrogen and phosphorus fluxes in Mexican coastal lagoons. LOICZ Reports and Studies, 10, 84pp, Texel, The Netherlands. 


\section{ACCEPTED MANUSCRIPT}

Smith, S. V., \& Crossland, C. J. Australian estuarine system: carbon, nitrogen and phosphorus fluxes. LOICZ Reports and Studies, 12, 182pp, LOICZ, Texel, The Netherlands.

Su, H. M, Lin, H. J., \& Hung, J. J. Effects of tidal flushing on phytoplankton in a eutrophic tropical lagoon in Taiwan. Estuarine Coastal and Shelf Science, $61,739-750$.

Tada, K, Morishita, M, Hamada, K. I, Montani, S., \& Yamada, M. (2001) Standing stock and production rate of phytoplankton and a red tide outbreak in a heavily eutrophic embayment, Dokai Bay, Japan. Marine Pollution Bulletin, 42, 1177-1186.

Twilley, R. R, Kemp, W. M, Staver, K. W, Stevenson, J. C., \& Boynton, WR. (1985) Nutrient enrichment of estuarine submersed vascular plant communities: 1 . Algal growth and effects on production of plants and associated communities. Marine Ecology Progress Series, 23, 179-191.

Wassmann, P., \& Tamminen, T. (1999) Pelagic eutrophication and sedimentation in the Gulf of Riga: a synthesis. Journal of Marine Systems, 23, 269-283.

Water Resource Planning Commission. (1997) Hydrological Year Book of Taiwan (400pp). Ministry of Economic Affairs, Republic of China.

Welschmeyer, N. A. (1994) Fluormetric analysis of chlorophyll a on the presence of chlorophyll b and pheopigments. Limnology and Oceanography, 39, 1985-1992.

Yu, C. S. (2001) Dynamic interaction and numeric simulation among Tapong Bay, 
Kaoping Estuary and Kaoping Canyon. Annual Report of National Science

Council, Taiwan (in Chinese).

\section{Figure captions.}

Fig. 1. Locations and sampling sites of Tapong Bay.

Fig. 2. Temporal variations of lagoon-averaged salinity, temperature, $\mathrm{pH}$ and $\mathrm{DO}$ in

Tapong Bay. The vertical dashed line indicates the separation of two periods before and after removal of the maricultural structures.

Fig. 3. Spatial distributions of DO in surface and bottom waters during summer for both before (Aug., 1999) and after (Aug., 2003) periods of structure removal.

Fig. 4. Spatial distributions of DIN in surface and bottom waters during summer for both before (Aug., 1999) and after (Aug., 2003) periods of structure removal. 
Fig. 5. Temporal variations of nutrient ratios for Si/DIP (a), Si/DIN (b) and DIN/DIP (c) in Tapong Bay. The vertical dashed line indicates the separation of two periods before and after removal of the maricultural structures.

Fig. 6. Comparisons of distributions for averaged total number of cell, Chl-a and integrated gross production between the periods before and after the structure removal. The bottom figure shows the sampling sites to collect large volumes of seawater for incubation experiments.

Fig. 7. Relation plots among temperature, solar irradiance, integrated DO and Chl-a (a), and relation plots among integrated Chl-a, integrated DIN and integrated DIP (b) before removal of the maricultural structures.

Fig. 8. Temporal variability of NEP $(p-r)$ in Tapong lagoon. The vertical dashed line indicates the separation of two periods before and after removal of the maricultural structures. 


\section{ACCEPTED MANUSCRIPT}

Table 1

Temporal variability of freshwater inputs and hydrochemical conditions in lagoon water.

\begin{tabular}{|c|c|c|c|c|c|c|c|c|}
\hline & \multirow{4}{*}{$\begin{array}{l}\text { Sampling } \\
\text { time }\end{array}$} & \multirow{2}{*}{\multicolumn{2}{|c|}{$\begin{array}{l}\text { Freshwater input } \\
\qquad\left(10^{3} \mathrm{~m}^{3} \mathrm{~d}^{-1}\right)\end{array}$}} & \multirow{2}{*}{\multicolumn{4}{|c|}{ Lagoon water }} & \multirow{4}{*}{$\begin{array}{c}\tau \\
(\text { day })^{\#}\end{array}$} \\
\hline & & & & & & & & \\
\hline & & \multirow{2}{*}{$\begin{array}{l}\text { Precipi- } \\
\text { tation }\end{array}$} & \multirow{2}{*}{$\begin{array}{c}\text { Evapo- } \\
\text { ration }\end{array}$} & \multirow{2}{*}{ Salinity } & \multirow{2}{*}{$\mathrm{pH}$} & \multicolumn{2}{|c|}{$\mathrm{DO}\left(\mathrm{mg} \mathrm{l}^{-1}\right)$} & \\
\hline & & & & & & surface & bottom & \\
\hline Before & Aug-1999 & 90 & 22 & 31.3 & 8.24 & 6.38 & 5.36 & 7 \\
\hline structure & Oct-1999 & 28 & 16 & 31.8 & 8.22 & 4.44 & 3.20 & 12 \\
\hline removal & Dec-1999 & 4 & 12 & 32.9 & 8.1 & 6.33 & 6.36 & 12 \\
\hline & Feb-2000 & 4 & 12 & 33.3 & 7.95 & 3.99 & 3.14 & 13 \\
\hline & Apr-2000 & 10 & 21 & 33.9 & 8.06 & 3.87 & 3.63 & 11 \\
\hline & Jun-2000 & 30 & 26 & 31.5 & 8.36 & 10.7 & 3.98 & 10 \\
\hline & Aug-2000 & 93 & 18 & 25.4 & 8.04 & 5.27 & 4.96 & 9 \\
\hline & Dec-2001 & 1 & 12 & 33.4 & 8.19 & 5.05 & 4.79 & 9 \\
\hline & July-2002 & 68 & 25 & 32.7 & 8.44 & 5.32 & 3.14 & 6 \\
\hline & Mean \pm sd* & $36 \pm 37$ & $18 \pm 6$ & $31.8 \pm 2.5$ & $8.22 \pm 0.15$ & $5.71 \pm 2.07$ & $4.28 \pm 1.14$ & $10 \pm 2$ \\
\hline After & Feb-2003 & 2 & 17 & 34.4 & 8.20 & 8.04 & 7.79 & 7 \\
\hline structure & May-2003 & 8 & 28 & 34.6 & 8.19 & 6.12 & 4.20 & 5 \\
\hline removal & Aug-2003 & 128 & & 30.4 & 8.19 & 10.3 & 5.71 & 6 \\
\hline & Nov-2003 & 10 & & 32.7 & 7.89 & 6.55 & 4.31 & 9 \\
\hline & Jun-2004 & 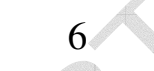 & 22 & 32.1 & 8.18 & 7.17 & 5.00 & 4 \\
\hline & Sep-2004 & & 22 & 31.3 & 8.18 & 8.35 & 5.65 & 5 \\
\hline & Mean \pm sd & $49 \pm 66$ & $21 \pm 5$ & $33 \pm 1.6$ & $8.14 \pm 0.12$ & $5.44 \pm 1.50$ & $6.10 \pm 1.31$ & $6 \pm 2$ \\
\hline
\end{tabular}

$*_{\text {sd: standard deviation }}{ }^{*} \tau$ : water exchange time 


\section{ACCEPTED MANUSCRIPT}

Table 2

Distributions of nutrients and dissolved organic matter averaged from all sampling stations during two separated periods

\begin{tabular}{|c|c|c|c|c|c|c|c|}
\hline \multirow{2}{*}{$\begin{array}{l}\text { Lagoon } \\
\text { Status }\end{array}$} & \multirow{2}{*}{$\begin{array}{l}\text { Sampling } \\
\text { Time }\end{array}$} & \multicolumn{3}{|c|}{ Nutrient $(\mu \mathrm{M})$} & \multicolumn{3}{|c|}{$\begin{array}{l}\text { Dissolved Organic } \\
\text { Matter }(\mu \mathrm{M})\end{array}$} \\
\hline & & $\mathrm{DSi}$ & DIN & DIP & DOC & DON & DOP \\
\hline \multirow{11}{*}{$\begin{array}{l}\text { Before } \\
\text { removal }\end{array}$} & Aug-1999 & 22.5 & 12 & 2.51 & 172.3 & 21 & 2.70 \\
\hline & Oct-1999 & 29.0 & 18 & 3.97 & 127.7 & 14 & 6.74 \\
\hline & Dec-1999 & 12.7 & 13 & 2.41 & 128.2 & 32 & 0.70 \\
\hline & Feb-2000 & 18.3 & 20 & 5.07 & 126.0 & 35 & 0.54 \\
\hline & Apr-2000 & 16.4 & 12 & 4.00 & 120.3 & 23 & 1.50 \\
\hline & Jun-2000 & 21.7 & 12 & 5.11 & 211.7 & 23 & 2.70 \\
\hline & Aug-2000 & 39.6 & 30 & 7.60 & 168.2 & 23 & 1.94 \\
\hline & Dec-2001 & 11.0 & 9.1 & 3.3 & 178.5 & - & - \\
\hline & Jul-2002 & 11.2 & 21.9 & 1.6 & 228.4 & - & - \\
\hline & Mean & 20.3 & 16.4 & 4.0 & 162.4 & 24.4 & 2.4 \\
\hline & $\pm \mathrm{sd}^{*}$ & \pm 9.4 & \pm 6.6 & \pm 1.8 & \pm 39.7 & \pm 7.0 & \pm 2.1 \\
\hline \multirow{8}{*}{$\begin{array}{c}\text { After } \\
\text { removal }\end{array}$} & Feb-2003 & 12.4 & 9.4 & 1.0 & 154.1 & 49.2 & 1.6 \\
\hline & May-2003 & 6.0 & 8.0 & 0.2 & 193.9 & 41.3 & 1.1 \\
\hline & Aug-2003 & 4.2 & 9.8 & 3.0 & 241.6 & 41.4 & 0.7 \\
\hline & Nov-2003 & 8.0 & 18.2 & 0.6 & 126.2 & 73.0 & 0.9 \\
\hline & Jun-2004 & 9.9 & 9.9 & 2.0 & 400.0 & 17.7 & 2.3 \\
\hline & Sep-2004 & 19.7 & 13.3 & 2.4 & 278.0 & 15.9 & 0.9 \\
\hline & Mean & 10.0 & 11.4 & 1.5 & 232.3 & 39.8 & 1.2 \\
\hline & $\pm \mathrm{sd}$ & \pm 5.5 & \pm 3.7 & \pm 1.1 & \pm 99.1 & \pm 21.2 & \pm 0.6 \\
\hline
\end{tabular}

*sd: standard deviation 


\section{ACCEPTED MANUSCRIPT}

Table 3

Comparison of nonconservative fluxes $\left(\mathrm{mmol} \mathrm{m}^{-2} \mathrm{~d}^{-1}\right)$ for carbon and nutrients between before and after removal of the maricultural structures

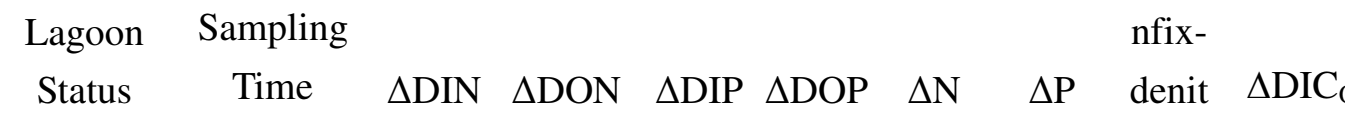

\begin{tabular}{|c|c|c|c|c|c|c|c|c|c|}
\hline \multicolumn{10}{|l|}{ Before } \\
\hline \multirow[t]{13}{*}{ removal } & Aug-1999 & -0.58 & 3.40 & -0.06 & 0.26 & 2.82 & 0.20 & -0.38 & -6.36 \\
\hline & Oct-1999 & -1.00 & 0.62 & -0.13 & 0.64 & -0.46 & 0.51 & -8.62 & -13.8 \\
\hline & Dec-1999 & -1.15 & 3.28 & -0.36 & -0.32 & 2.25 & -0.68 & 13.1 & -38.2 \\
\hline & Feb-2000 & -0.28 & 3.21 & 0.02 & -0.38 & 3.04 & -0.36 & 8.80 & 2.12 \\
\hline & Apr-2000 & 0.92 & 1.51 & -0.02 & 0.06 & 2.52 & 0.04 & 1.88 & -2.12 \\
\hline & Jun-2000 & -0.08 & 1.89 & -0.08 & 0.26 & 1.60 & 0.18 & -1.28 & -8.48 \\
\hline & Aug-2000 & 2.28 & -1.53 & -0.42 & -0.25 & 0.66 & -0.67 & 11.4 & -44.5 \\
\hline & Dec-2001 & 1.21 & - & -0.04 & - & 1.21 & -0.04 & 1.85 & -4.66 \\
\hline & Jul-2002 & 3.74 & - & -0.22 & - & 3.74 & -0.22 & 7.26 & -23.0 \\
\hline & Mean & 0.56 & 1.77 & -0.15 & 0.04 & 1.93 & -0.12 & 3.78 & -15.4 \\
\hline & $\pm \mathrm{sd}^{*}$ & \pm 1.63 & \pm 1.79 & \pm 0.15 & \pm 0.37 & \pm 1.31 & \pm 0.40 & \pm 6.94 & \pm 16.4 \\
\hline & Annual & 0.21 & 0.65 & -0.05 & 0.01 & 0.70 & -0.04 & 1.38 & -5.6 \\
\hline & mean\# & \pm 0.61 & \pm 0.67 & \pm 0.05 & \pm 0.14 & \pm 0.49 & \pm 0.15 & \pm 2.60 & \pm 6.1 \\
\hline After & Feb-2003 & -4.90 & -5.70 & -1.20 & 0.02 & -10.6 & -1.18 & 8.35 & -127 \\
\hline \multirow[t]{9}{*}{ removal } & Мay-2003 & -1.88 & 12.6 & -0.02 & -0.51 & 10.74 & -0.53 & 19.2 & -2.01 \\
\hline & Aug-2003 & -2.05 & 6.27 & 0.25 & -1.16 & 4.22 & -0.91 & 18.7 & 26.7 \\
\hline & Nov-2003 & -1.23 & 10.0 & -0.23 & 0.01 & 8.79 & -0.23 & 12.4 & -24.7 \\
\hline & Jul-2004 & -3.47 & 4.15 & -0.05 & 0.48 & 0.68 & 0.44 & -6.30 & -5.30 \\
\hline & Sep-2004 & -1.69 & 3.75 & 0.044 & -0.06 & 2.06 & -0.012 & 2.25 & 4.16 \\
\hline & Mean & -2.54 & 5.18 & -0.20 & -0.20 & 2.65 & -0.40 & 9.1 & -21.2 \\
\hline & $\pm \mathrm{sd}$ & \pm 1.38 & \pm 6.33 & \pm 0.51 & \pm 0.56 & \pm 7.55 & \pm 0.59 & \pm 9.9 & \pm 54.3 \\
\hline & Annual & -0.93 & 1.89 & -0.07 & -0.07 & 0.97 & -0.15 & 3.32 & -7.7 \\
\hline & mean\# & \pm 0.51 & \pm 2.37 & \pm 0.19 & \pm 0.21 & \pm 2.83 & \pm 0.22 & \pm 3.71 & \pm 20.4 \\
\hline
\end{tabular}

\#Annual mean ( $\left.\mathrm{mol} \mathrm{m}^{-2} \mathrm{yr}^{-1}\right) \quad$ *sd: standard deviation 


\section{ACCEPTED MANUSCRIPT}

Table 4

Comparisons of hydrochemical variables, nutrients, and ecosystem properties measured before and after removal of maricultural rafts. $\mathrm{P}$ values are results from One-Way ANOVA tests comparing variables (means of all stations for each sampling date) before (1999-2001) and after (2003-2004) rafts removal. Abbreviations for variables represent: $\mathrm{DO}=$ dissolved oxygen; Net $\mathrm{ppt}=$ net precipitation; 'WET $=$ water exchange time; GP = gross production; Phytopl = total phytoplankton; Zoopl = zooplankton; $\mathrm{NEP}=$ net ecosystem production; $\mathrm{NT}=$ not tested .

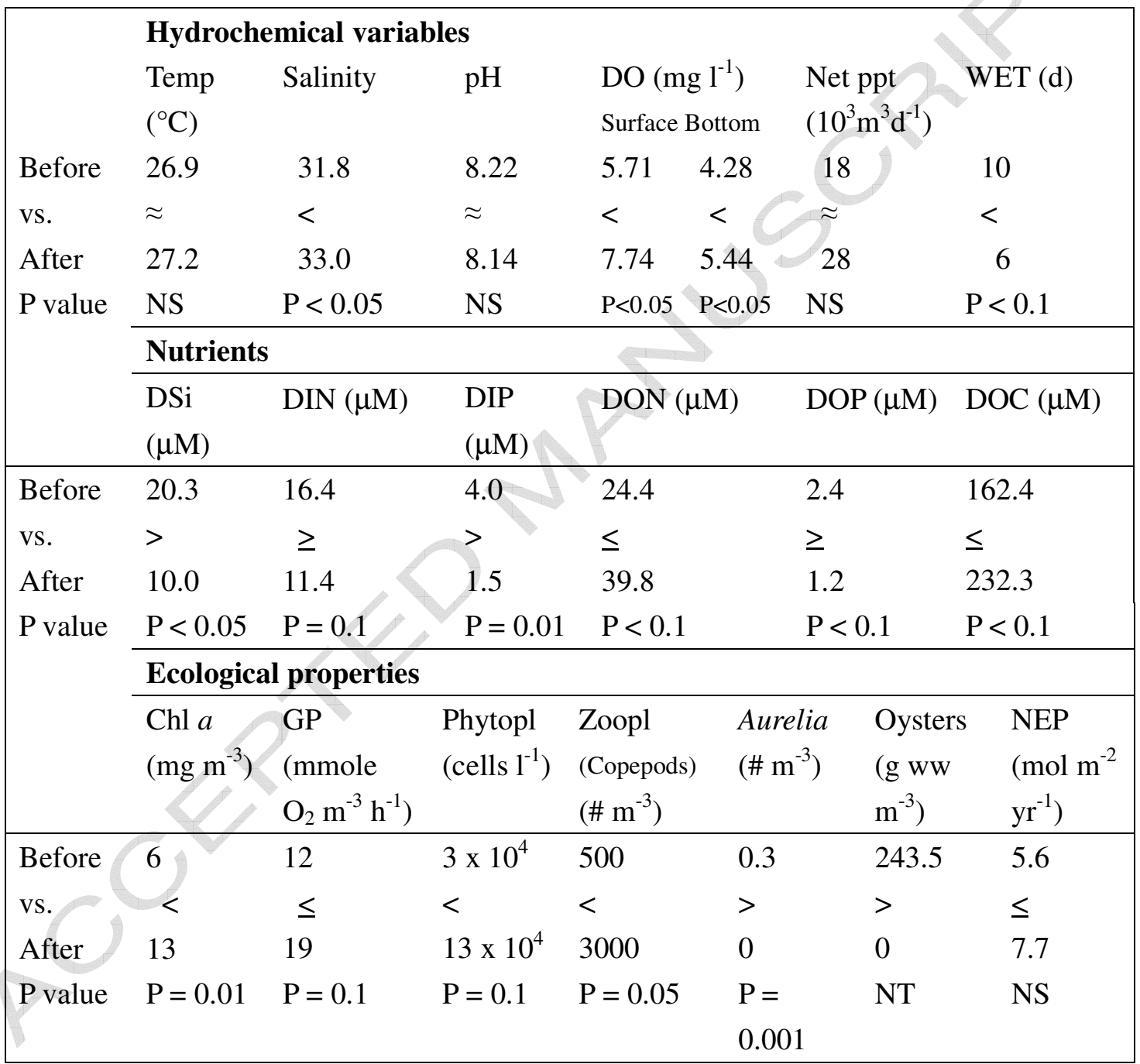




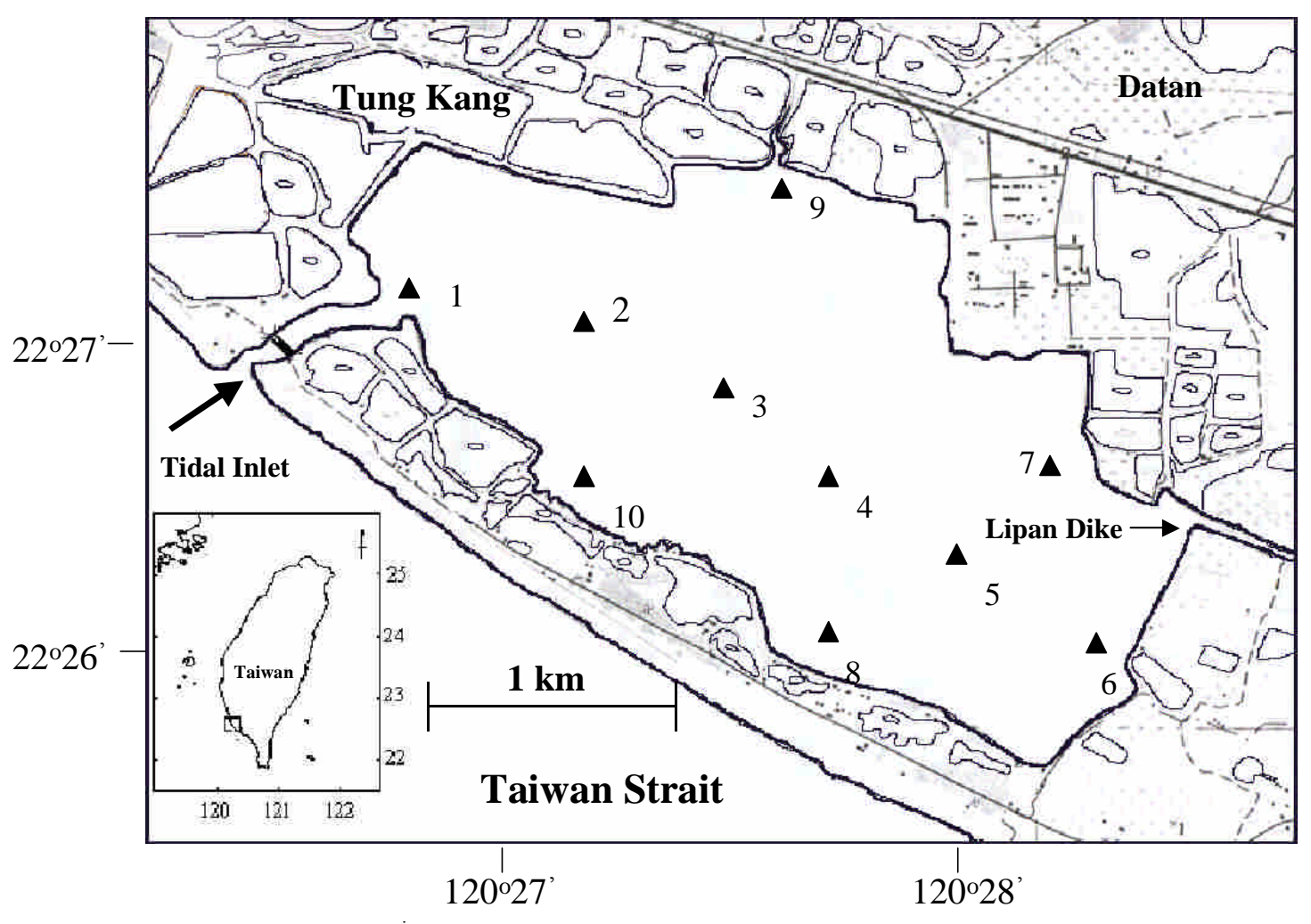

Fig. 1 


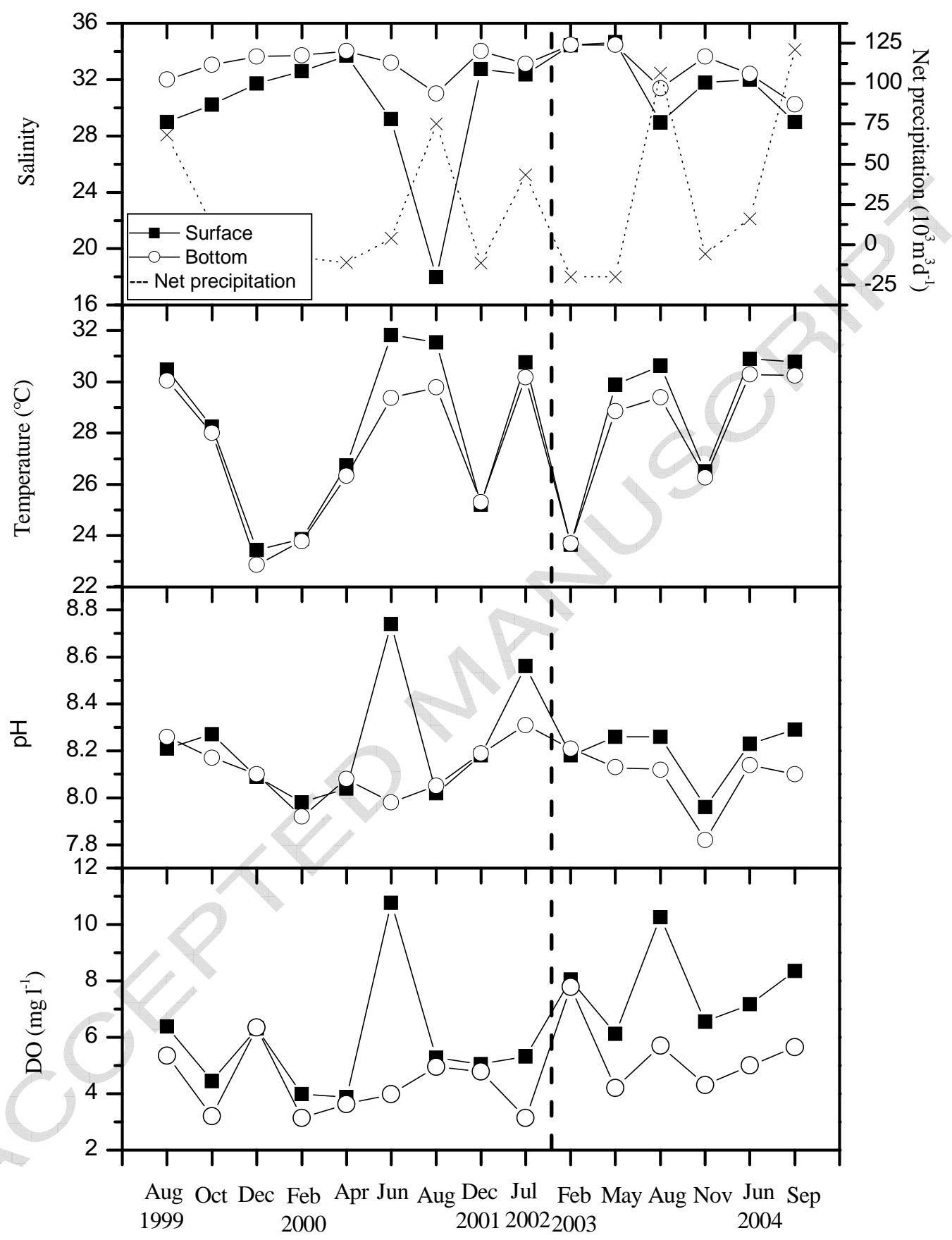

Fig. 2 


\section{ACCEPTED MANUSCRIPT}
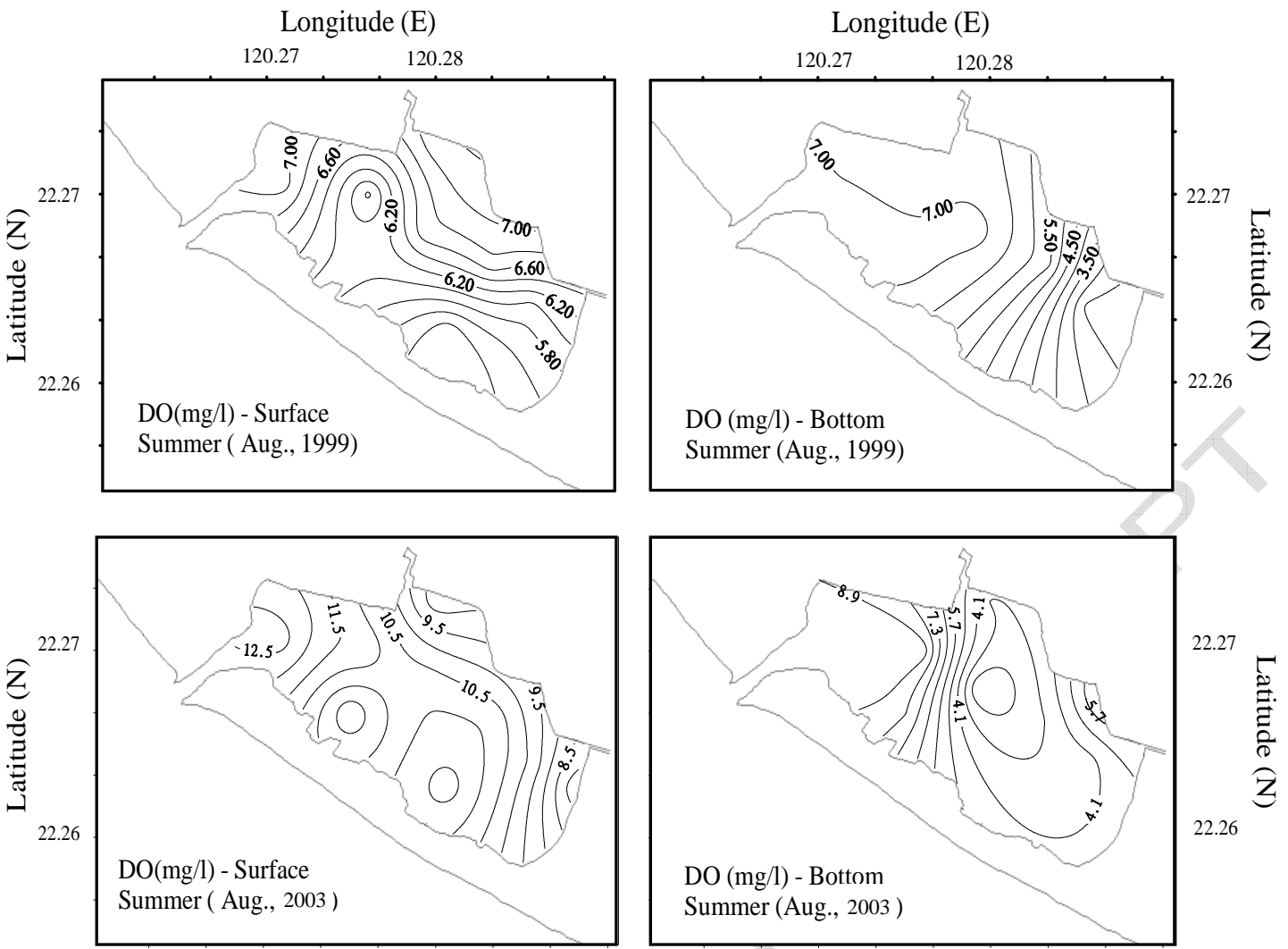

Fig. 3 


\section{ACCEPTED MANUSCRIPT}
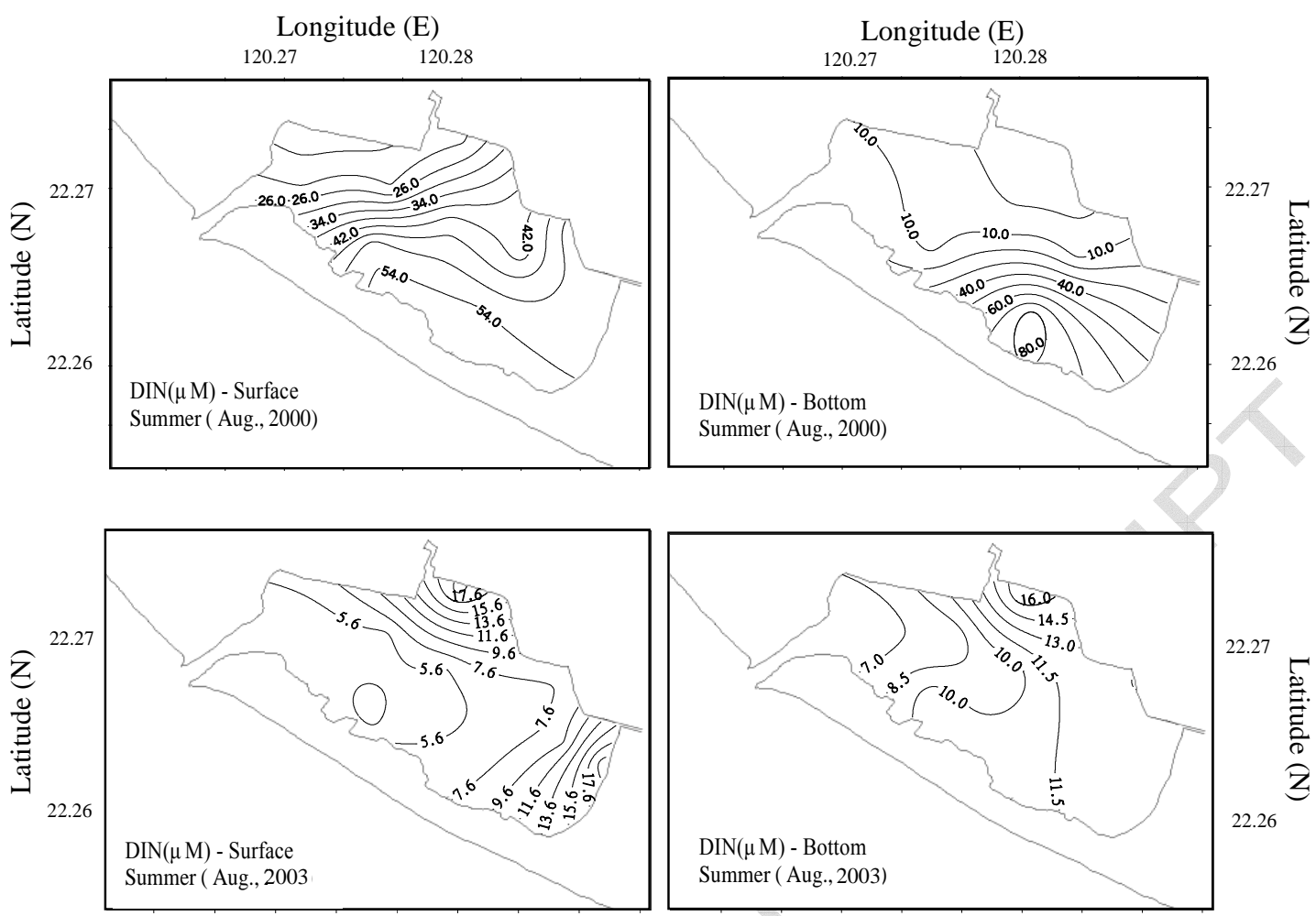

Fig. 4 


\section{ACCEPTED MANUSCRIPT}

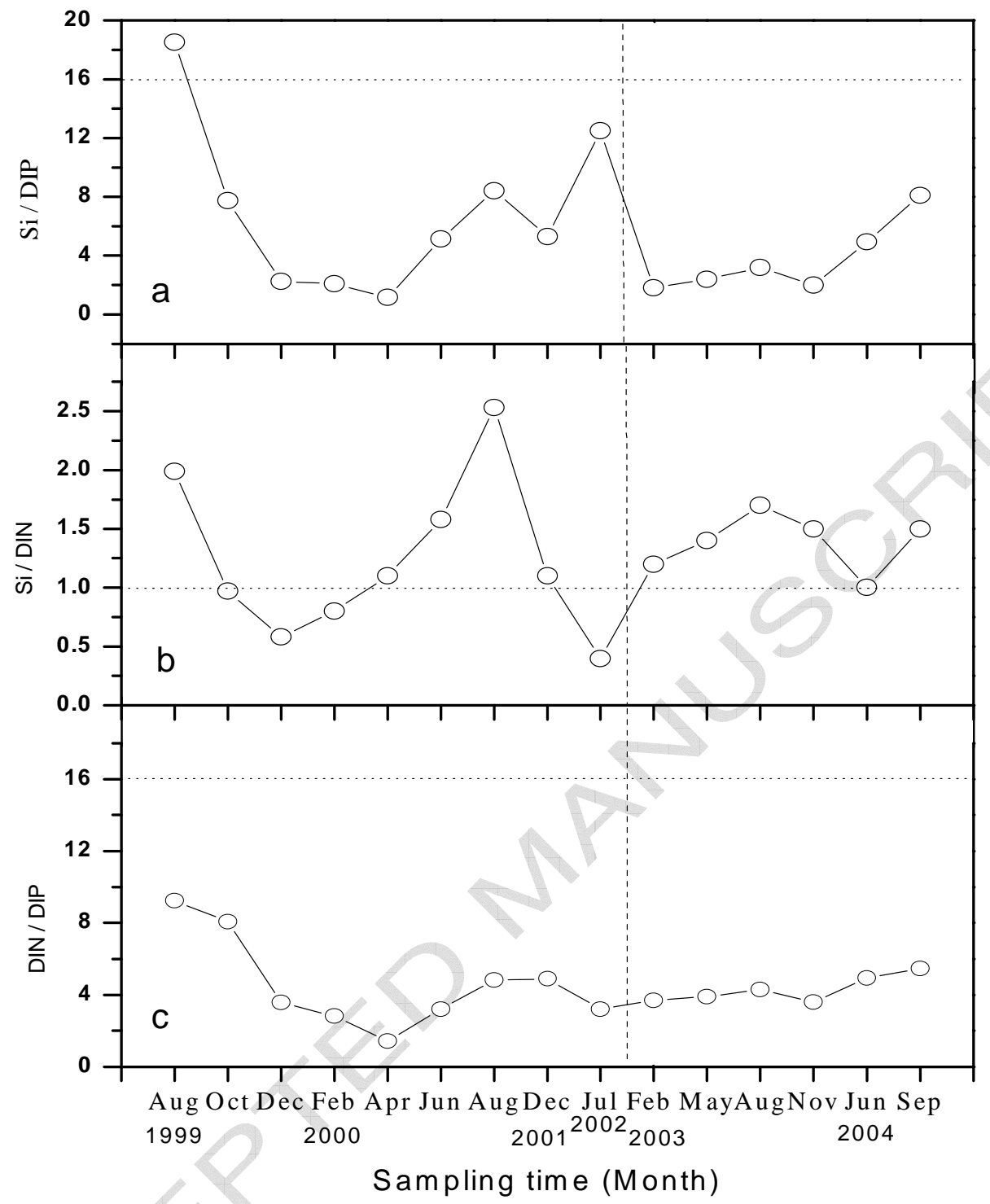

Fig. 5 

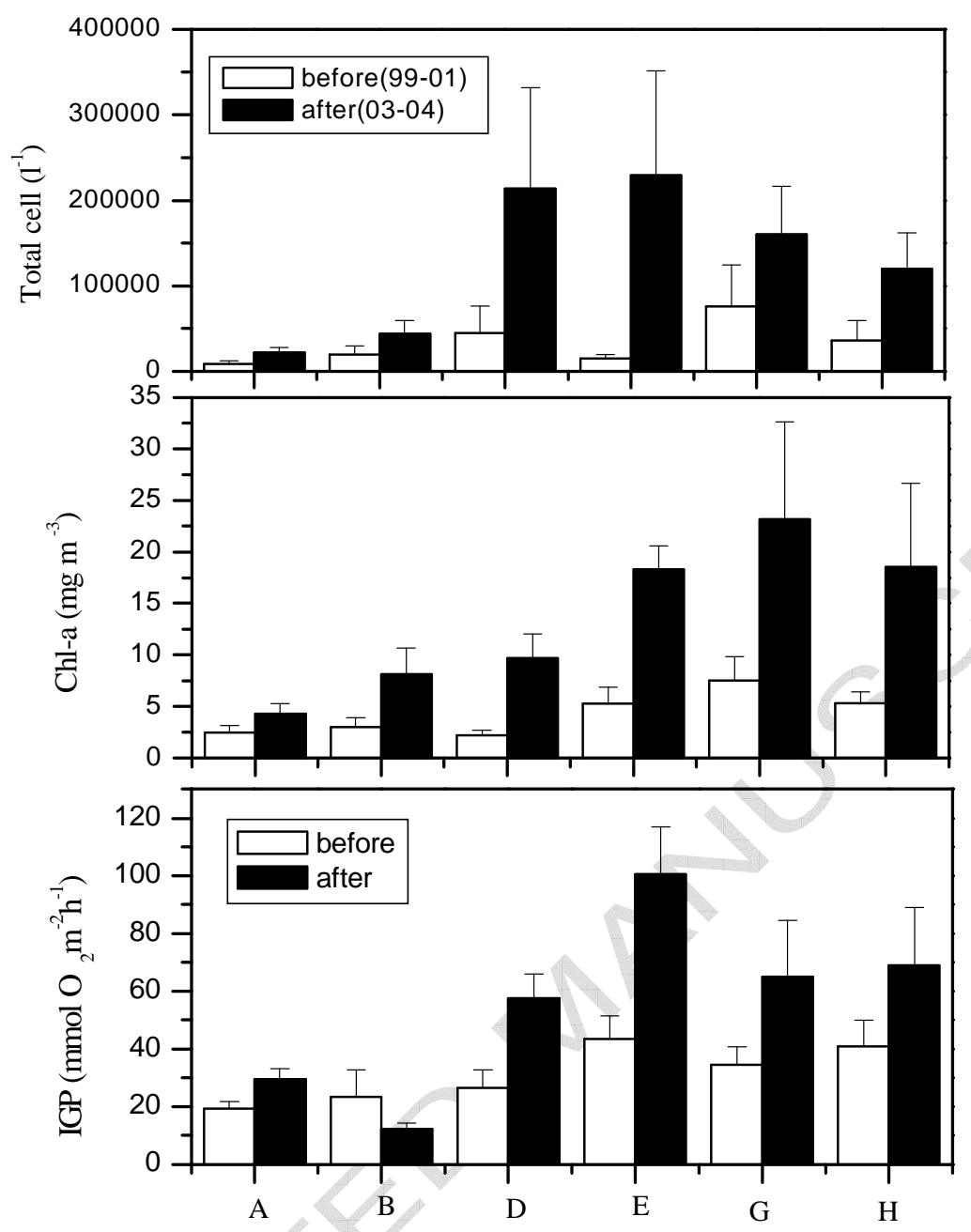

Station

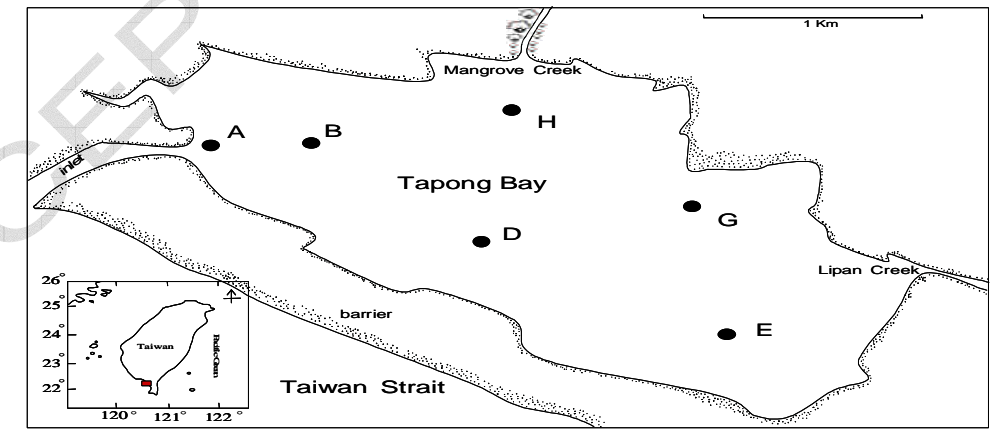

Fig. 6 

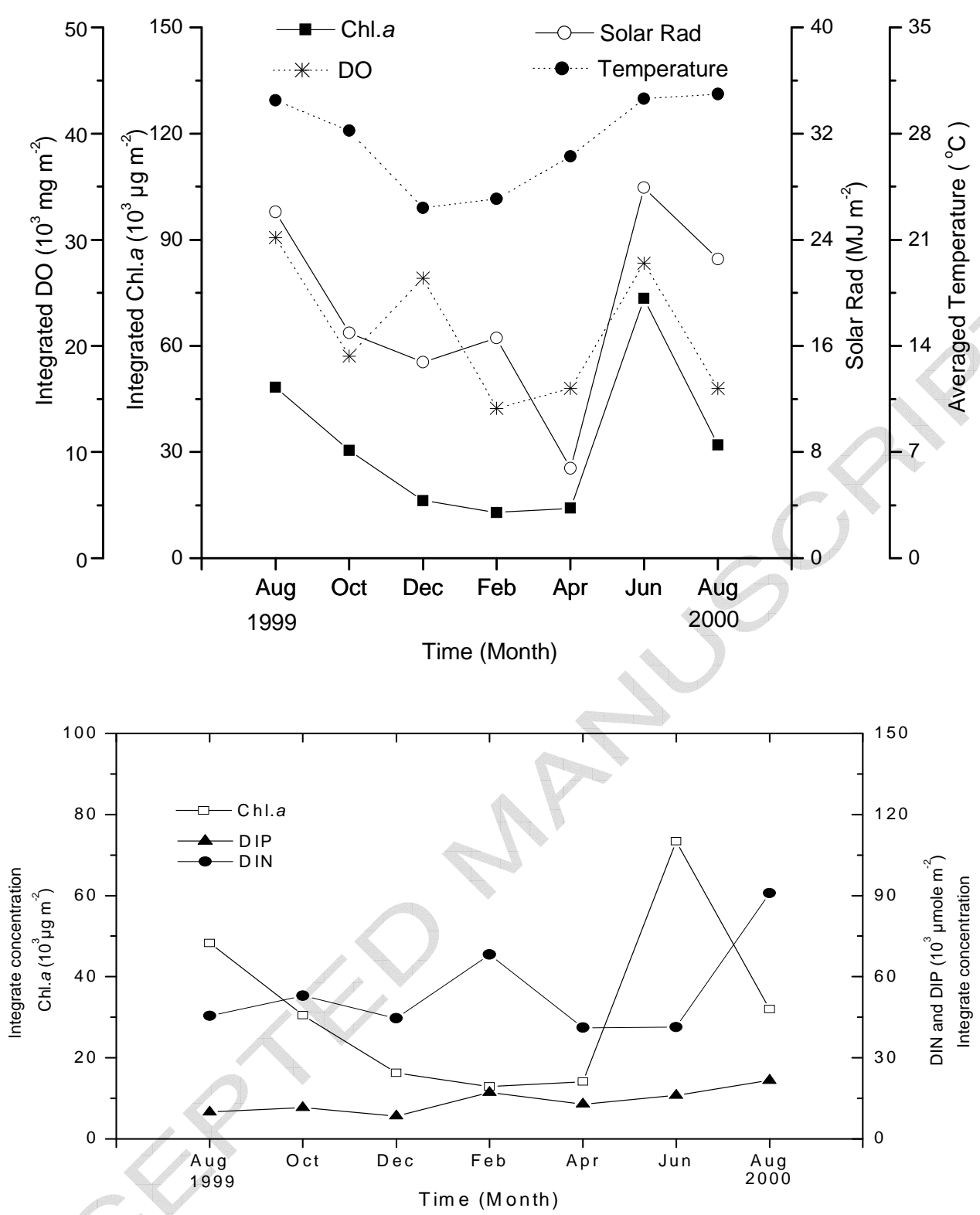

Fig. 7 


\section{ACCEPTED MANUSCRIPT}

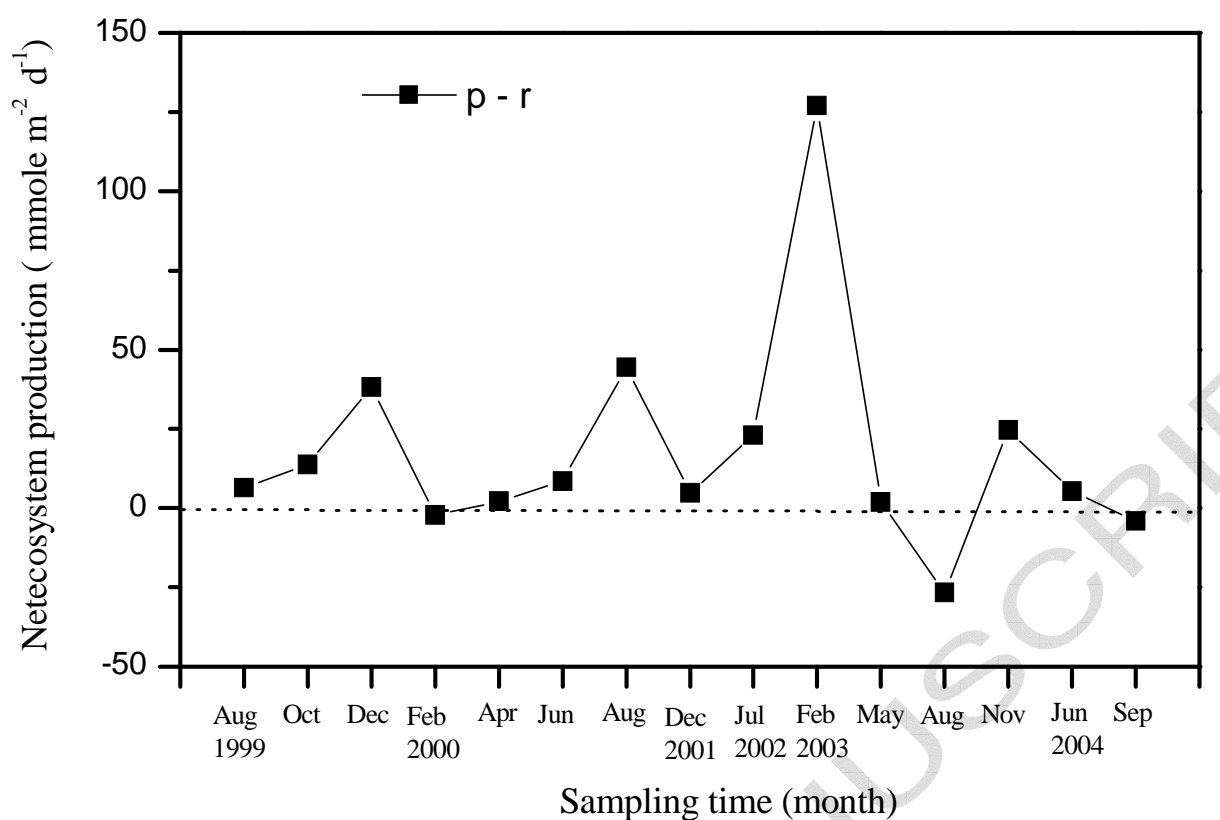

Fig. 8 